${ }^{1}$ Department of Pathology and Laboratory Medicine, Indiana University School of Medicine, Indianapolis, Indiana, USA ${ }^{2}$ Department of Pathology, University of Erlangen, Erlangen, Germany

${ }^{3}$ Biocare Medical, Concord, California, USA

${ }^{4}$ Department of Pathological Anatomy and Histopathology, School of Medicine, Polytechnic University of the Marche Region (Ancona), Ancona, Italy 5 Department of Pathology, Cordoba University, Cordoba, Spain

\section{Correspondence to} Dr Liang Cheng, Department of Pathology, Indiana University School of Medicine, 350 West 11th Street, IU Health Pathology Laboratory, Room 4010, Indianapolis, IN 46202, USA: liang_cheng@yahoo.com

Accepted 8 November 2011 Published Online First

1 December 2011

\title{
PAX8 is expressed in the majority of renal epithelial neoplasms: an immunohistochemical study of 223 cases using a mouse monoclonal antibody
}

\author{
Yingchuan Hu, ${ }^{1}$ Arndt Hartmann, ${ }^{2}$ Christine Stoehr, ${ }^{2}$ Shaobo Zhang, ${ }^{1}$ \\ Mingsheng Wang, ${ }^{1}$ David Tacha, ${ }^{3}$ Rodolfo Montironi, ${ }^{4}$ Antonio Lopez-Beltran, ${ }^{5}$ \\ Liang Cheng ${ }^{1}$
}

\section{ABSTRACT}

Aims PAX8 is a cell lineage-specific transcription factor which plays a crucial role in the organogenesis of the kidney, thyroid gland and Müllerian duct. A previous study showed that PAX8 is a specific and sensitive marker for both renal and ovarian carcinomas. The purpose of this study is to investigate PAX8 expression using a new monoclonal PAX8 antibody in a larger number of renal epithelial neoplasms including clear cell renal cell carcinoma, papillary renal cell carcinoma, chromophobe renal cell carcinoma and renal oncocytoma.

Methods PAX8 immunohistochemical staining was performed on tissue microarrays containing 84 cases of clear cell renal cell carcinoma, 66 cases of chromophobe renal cell carcinoma, 57 cases of papillary renal cell carcinoma and 16 cases of renal oncocytoma.

Results PAX8 expression was detected in 93\% (78/84) of cases of clear cell renal cell carcinoma, $80 \%(53 / 66)$ of cases of chromophobe renal cell carcinoma, 95\% (54/ 57) of cases of papillary renal cell carcinoma and $94 \%$ $(15 / 16)$ of cases of renal oncocytoma.

Conclusions PAX8 is expressed in the majority of renal epithelial neoplasms including renal cell carcinomas and oncocytomas and the monoclonal PAX8 antibody is more sensitive than polyclonal antibody to detect chromophobe renal cell carcinoma. These results showed that PAX8 is a valuable marker for nephric neoplasms.

\section{INTRODUCTION}

PAX8 is a cell lineage-specific transcription factor which plays a crucial role in the organogenesis of the kidney, thyroid gland and Müllerian duct. Our previous study using a rabbit polyclonal antibody anti-PAX8 in a wide variety of normal and neoplastic tissues showed that PAX8 is a sensitive and specific marker for both renal and ovarian carcinomas. ${ }^{1}$ While there are several studies including ours on renal cell carcinomas using polyclonal PAX8 antibody immunohistochemistry, ${ }^{1-3}$ the information for a new monoclonal PAX8 antibody in renal epithelial neoplasms is very limited. Therefore, using a new monoclonal PAX8 antibody, this study aims to investigate PAX8 expression in a larger number (223 cases) of renal epithelial neoplasms including 84 cases of clear cell renal cell carcinoma, 57 cases of papillary renal cell carcinoma, 66 cases of chromophobe renal cell carcinoma and 16 cases of renal oncocytoma.

\section{MATERIALS AND METHODS}

\section{Construction of tissue microarrays}

Tissue microarrays, containing 223 cases of human renal epithelial neoplasms including 84 cases of clear cell renal cell carcinoma, 66 cases of chromophobe renal cell carcinoma, 57 cases of papillary renal cell carcinoma and 16 cases of renal oncocytoma, were constructed as previously described ${ }^{4} 5$ at the Institute for Pathology, University of Erlangen, Germany. All tumours were reviewed by an experienced uropathologist and diagnosis of the histological type according to the 2004 WHO classification $^{6}$ was confirmed. Sections of $5 \mu \mathrm{m}$ thickness were cut from tissue microarrays and were stained with $\mathrm{H} \& \mathrm{E}$ to confirm the presence of the expected tumour histology within each tissue core. Additional sections were cut for immunohistochemistry.

\section{Immunohistochemistry}

Tissue sections from the tissue microarray were deparaffinized, rehydrated using graded alcohols and washed with tris buffered saline. Antigen retrieval for PAX8 was performed by heating sections at $125^{\circ} \mathrm{C}$ in a pressure cooker for $20 \mathrm{~min}$. After endogenous peroxidase activity was quenched and non-specific binding was blocked, tissue sections were incubated with mouse monoclonal antibody PAX8 (BC12, Biocare Medical, Concord, California, USA) for $30 \mathrm{~min}$. Sections were then rinsed and incubated in a polymer HRP-detection system for $30 \mathrm{~min}$ and visualised with diaminobenzidine $(\mathrm{DAB})$ chromogen. Slides were briefly counterstained in a modified Mayer haematoxylin. A normal renal tissue served as positive control. Negative control was performed by replacing the PAX8 antibody with normal serum. Only nuclear staining was considered positive.

\section{RESULTS}

The results of PAX8 immunohistochemical staining are summarised in table 1 and figure 1 . Overall, 90\% (200/223) of all renal epithelial neoplasms stained positive for PAX8. Among renal cell carcinomas, PAX8 expression was detected in $93 \%(78 / 84)$ of cases of clear cell renal cell carcinoma, in $80 \%(53 / 66)$ of cases of chromophobe renal cell carcinomas and in $95 \%(54 / 57)$ of cases of papillary renal cell carcinoma. PAX8 expression was detected in $94 \%(15 / 16)$ of cases of renal oncocytoma. 
Table 1 Summary of PAX8 immunostaining in renal epithelial neoplasms

\begin{tabular}{lccc}
\hline & n & Negative (\%) & Positive (\%) \\
\hline Clear cell renal cell carcinoma & 84 & $6(7)$ & $78(93)$ \\
Chromophobe renal cell carcinoma & 66 & $13(20)$ & $53(80)$ \\
Papillary renal cell carcinoma & 57 & $3(5)$ & $54(95)$ \\
Renal oncocytoma & 16 & $1(6)$ & $15(94)$ \\
Total & 223 & $23(10)$ & $200(90)$ \\
\hline
\end{tabular}

\section{DISCUSSION}

In this study, using a monoclonal PAX8 antibody, we found that $90 \%(200 / 223)$ of renal epithelial neoplasms were positive for PAX8. Among renal cell carcinomas, papillary renal cell carcinomas had the highest percentage of positivity for PAX8, followed by clear cell renal cell carcinomas and chromophobe renal cell carcinomas. Most renal oncocytomas were positive for PAX8. These findings confirm earlier studies by us and other groups using a polyclonal PAX8 antibody and further show that PAX8 is a very useful immunomarker for renal epithelial neoplasm. ${ }^{1-3}$

PAX8 is one of the nine members of the paired box (PAX) family of cell lineage transcription factors, which play crucial roles during fetal development and neoplastic growth. ${ }^{3-9}$ PAX8 is a nephric lineage nuclear transcription factor which plays an important role in renal organogenesis. ${ }^{3}{ }^{10-14}$ PAX8 may also be involved in maintaining the differentiated features and specialised functions of renal epithelial cells. ${ }^{15}{ }^{16}$ Our previous study, using a rabbit polyclonal PAX8 antibody, found PAX8 positivity in $91 \%(86 / 94)$ of clear cell renal cell carcinomas, $100 \%(14 / 14)$ of papillary renal cell carcinomas and $57 \%$ (4/7) of chromophobe renal cell carcinomas. ${ }^{1}$ The current study with a mouse monoclonal antibody showed that $93 \%$ of clear cell renal cell carcinomas, $95 \%$ of papillary renal cell carcinomas and $80 \%$ of chromophobe renal cell carcinomas were positive for PAX8. These findings are similar to those from other groups and our previous study using polyclonal PAX8 antibody with the exception of a lower positive rate for chromophobe renal cell carcinoma ( $57 \%$ vs $80 \%$ ). The lower positive rate in our previous study may be due to the limited number (only seven cases) of chromophobe renal cell carcinomas. Our current study, which consisted of a larger number of cases, further confirmed our previous findings that chromophobe renal cell carcinoma has the lowest PAX8 positive rate among the common renal cancers. ${ }^{1}$ These findings are consistent with those reported by Laury et al. ${ }^{2}$

Using a polyclonal PAX8 antibody, Laury et al found that $93 \%$ $(115 / 123)$ of clear cell renal cell carcinomas, $76 \%(19 / 25)$ of papillary renal cell carcinomas, $80 \%(4 / 5)$ of chromophobe renal cell carcinomas and $81 \%(13 / 16)$ of renal oncocytomas were
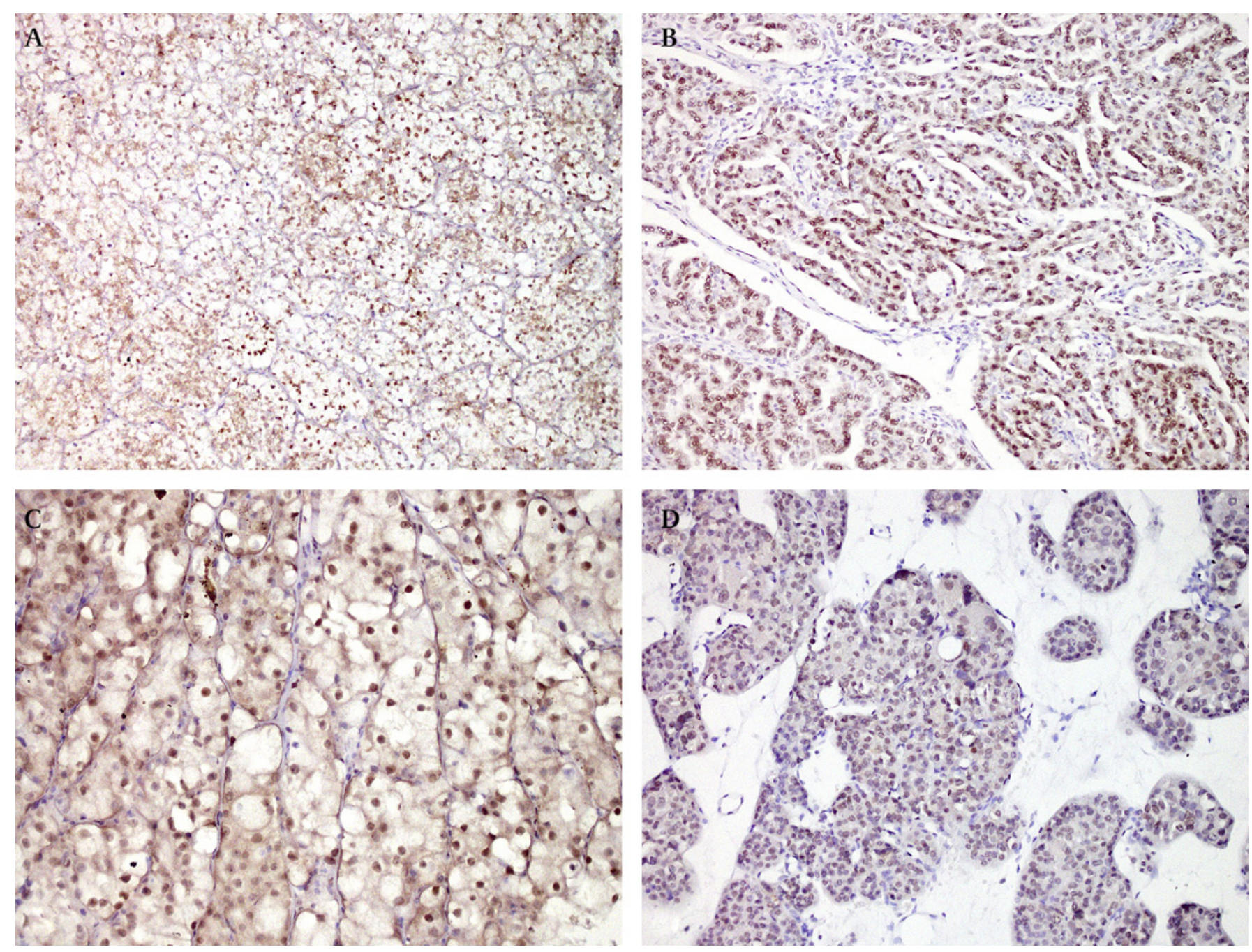

Figure 1 Immunohistochemical staining of PAX8 in renal epithelial neoplasms. Positivity for PAX8 was seen in clear cell renal cell carcinoma (A), papillary renal cell carcinoma (B), chromophobe renal cell carcinoma (C) and renal oncocytoma (D) (magnification $200 \times$ ). 


\section{Take-home messages}

- PAX8 is a cell lineage-specific transcription factor which plays a crucial role in the organogenesis of the kidney, thyroid gland and Müllerian duct.

- PAX8 is expressed in the majority of renal epithelial neoplasms.

- Chromophobe renal cell carcinoma has a lower PAX8 positive rate among the common renal tumour types.

positive for PAX8. ${ }^{2}$ Similarly, using a polyclonal PAX8 antibody, Tong et al detected PAX8 positivity in 98\% (58/59) of clear cell renal cell carcinomas, $90 \%$ (19/21) of papillary renal cell carcinomas, $82 \%(9 / 11)$ of chromophobe renal cell carcinomas and $95 \%(21 / 22)$ of renal oncocytomas. ${ }^{3}$ Our findings are very similar to those reported by Laury et al and Tong et al, with the exception of a slightly higher positive rate $(95 \%)$ in papillary renal cell carcinomas in our current study of 223 cases of renal tumours. ${ }^{2} 3$

Tissue microarray immunohistochemistry is a very useful screening tool to identify promising biomarkers. ${ }^{4}$ However, its limitation should be realised as the positive rate in the current study may be underestimated when dealing with heterogeneous expressions, such as PAX8. Previous studies by our group and other groups have shown that the concordance between tissue microarray and whole section is over $90 \%$ as representative areas based on whole section reviews were preselected to construct the tissue microarray. Our results in the current study are similar to those reported by other groups. ${ }^{1-3}$

In summary, our results in the 223 cases of renal epithelial neoplasms showed that PAX8 is expressed in a high percentage (90\%) of renal neoplasms including both malignant renal tumours (renal cell carcinomas, 80-95\%) and benign renal tumours (oncocytomas, 94\%), which in turn confirm that PAX8 is a valuable marker for nephric tumours.
Competing interests None.

Provenance and peer review Not commissioned; externally peer reviewed.

\section{REFERENCES}

1. Tacha D, Zhou D, Cheng L. Expression of PAX8 in normal and neoplastic tissues: a comprehensive immunohistochemical study. Appl Immunohistochem Mol Morphol 2011;19:293-9.

2. Laury AR, Perets $\mathrm{R}$, Piao $\mathrm{H}$, et al. A comprehensive analysis of PAX8 expression in human epithelial tumors. Am J Surg Pathol 2011;35:816-26.

3. Tong GX, Yu WM, Beaubier NT, et al. Expression of PAX8 in normal and neoplastic renal tissues: an immunohistochemical study. Mod Pathol 2009;22:1218-27.

4. Bubendorf L. High-throughput microarray technologies: from genomics to clinics. Eur Urol 2001;40:231-8.

5. Singer K, Kastenberger M, Gottfried E, et al. Warburg phenotype in renal cell carcinoma: high expression of glucose-transporter 1 (GLUT-1) correlates with low CD8(+) T-cell infiltration in the tumor. Int J Cancer 2011;128:2085-95.

6. Eble JN, Sauter G, Epstein JI, et al. World Health Organization Classification of Tumours: Pathology and Genetics of Tumours of the Urinary System and Male Genital Organs. Lyon: IARC Press, 2004.

7. Bowen NJ, Logani S, Dickerson EB, et al. Emerging roles for PAX8 in ovarian cancer and endosalpingeal development. Gynecol Oncol 2007;104:331-7.

8. Nonaka D, Chiriboga L, Soslow RA. Expression of pax8 as a useful marker in distinguishing ovarian carcinomas from mammary carcinomas. Am J Surg Pathol 2008;32:1566-71.

9. Nonaka D, Tang Y, Chiriboga L, et al. Diagnostic utility of thyroid transcription factors Pax8 and TTF-2 (FoxE1) in thyroid epithelial neoplasms. Mod Pathol 2008;21:192-200.

10. Tong GX, Weeden EM, Hamele-Bena D, et al. Expression of PAX8 in nephrogenic adenoma and clear cell adenocarcinoma of the lower urinary tract: evidence of related histogenesis? Am J Surg Pathol 2008;32:1380-7.

11. Chi N, Epstein JA. Getting your Pax straight: Pax proteins in development and disease. Trends Genet 2002;18:41-7.

12. Poleev A, Fickenscher $\mathrm{H}$, Mundlos S, et al. PAX8, a human paired box gene: isolation and expression in developing thyroid, kidney and Wilms' tumors. Development 1992;116:611-23.

13. Dressler GR. The cellular basis of kidney development. Annu Rev Cell Dev Biol 2006;22:509-29.

14. Bouchard M, Souabni A, Mandler M, et al. Nephric lineage specification by Pax2 and Pax8. Genes Dev 2002;16:2958-70.

15. Narlis M, Grote D, Gaitan Y, et al. Pax2 and pax8 regulate branching morphogenesis and nephron differentiation in the developing kidney. J Am Soc Nephrol 2007; 18:1121-9.

16. Blake JA, Thomas M, Thompson JA, et al. Perplexing Pax: from puzzle to paradigm. Dev Dyn 2008;237:2791-803. 


\section{$J C P$}

PAX8 is expressed in the majority of renal epithelial neoplasms: an immunohistochemical study of 223 cases using a mouse monoclonal antibody

Yingchuan Hu, Arndt Hartmann, Christine Stoehr, Shaobo Zhang, Mingsheng Wang, David Tacha, Rodolfo Montironi, Antonio Lopez-Beltran and Liang Cheng

J Clin Pathol 2012 65: 254-256 originally published online December 1, 2011

doi: 10.1136/jclinpath-2011-200508

Updated information and services can be found at:

http://jcp.bmj.com/content/65/3/254

These include:

References This article cites 15 articles, 3 of which you can access for free at: http://jcp.bmj.com/content/65/3/254\#BIBL

Email alerting Receive free email alerts when new articles cite this article. Sign up in the service box at the top right corner of the online article.

Topic Articles on similar topics can be found in the following collections Collections

\section{Notes}

To request permissions go to:

http://group.bmj.com/group/rights-licensing/permissions

To order reprints go to:

http://journals.bmj.com/cgi/reprintform

To subscribe to BMJ go to:

http://group.bmj.com/subscribe/ 